PLURAL, Revista do Programa de Pós-Graduação em Sociologia da USP, São Paulo, v. 16, n. 1, pp. 11-37, 2009

\title{
Rawls e Habermas: em Busca de uma Perspectiva Democrática Transcontextual
}

\section{Pedro Herculano Guimarães Ferreira de Souza*}

Resumo: Este artigo busca analisar as contribuições de John Rawls e de Jürgen Habermas para a elaboração de uma teoria da justiça que recupere a dimensão moral da democracia liberal e possa ajudar a combater a crise de legitimidade enfrentada pelo Estado moderno. Apesar da chamada "virada linguística", ocorrida no campo da filosofia política no último século e do suposto fim das Grandes Narrativas, os dois pensadores se notabilizam por permanecerem fiéis à tradição universalista kantiana, em suas teorias procedimentalistas que procuram desfazer a oposição entre as "liberdades dos antigos" e as "liberdades dos modernos". Procuramos, aqui, analisar a lógica que guiou a construçấo de cada autor e também o debate amigável travado entre eles para mostrar como ambos são exemplares tanto das potencialidades quanto dos limites desse paradigma. Dessa maneira, terminamos por sugerir que tais limites podem ser superados pela adoção de uma perspectiva comunitarista que adota um ponto de vista autorreflexivo, o qual concebe a universalidade da justiça de forma imanente, abdicando da necessidade de um momento universal de consenso racional. Palavras-chave: teoria democrática; teoria política; ação comunicativa; Rawls; Habermas; procedimentalismo; liberalismo político.

\section{Rawls \& Habermas: in the Search for a Transcontextual Democratic Approach}

Abstract: This paper tries to assess John Rawls' and Jürgen Habermas' contribuitions to the development of a theory of justice that is able to salvage the moral dimension of liberal democracy and fend off the crisis of legitimacy faced by the modern State. Despite the "linguistic turn" that took place in the field of political philosophy in the last century and the alleged decline of

\footnotetext{
* Mestre em Sociologia pelo Instituto Universitário de Pesquisas do Estado do Rio de Janeiro (Iuperj) e doutorando também pelo Iuperj.
} 
the Grand Narratives, both thinkers are known for their steadfast attachment to the kantian universalist tradition with their proceduralist theories that seek to dillute the opposition between the "liberty of the ancients" and the "liberty of the moderns". In this paper we attempt to analyze the underlying logic behind each author's arguments and also the friendly debate in which they engaged, showing how their work is exemplary of the potentialities and the limits of the same paradigm. Finally, we suggest that those limits can be transcended through the adoption of a self-reflexive point of view which conceives the universality of Justice in an immanent way, pushing aside the need of an universal moment of rational consensus.

Keywords: democratic theory; political theory; communicative action; Rawls; Habermas; proceduralism; political liberalism.

\section{INTRODUÇÃO}

Ao longo do último século, não foram poucos os autores que se dedicaram a questionar e a desconstruir o conceito moderno de "razão" e a própria noçáo de modernidade, principalmente a partir da chamada "virada linguística", impulsionada, entre outras, pelas reflexôes de Wittgenstein acerca dos jogos de linguagem.

Em 1979, Lyotard declarou a obsolescência das Grandes Narrativas como fruto de um desgaste interno do princípio de legitimidade do conhecimento (1984, p. 39). Mais ainda, Foucault (1984) recorreu a Kant e a Baudelaire para defender seu método arqueológico e para caracterizar a modernidade como uma "atitude" ante a realidade contemporânea, na qual a questáo principal não é mais - como para Kant - a busca por estruturas formais de valor universal, mas, muito pelo contrário, o descobrimento de tudo o que existe de singular, arbitrário e contingente naquelas estruturas que se apresentam como universais e necessárias.

Nesse contexto, é notável que John Rawls (I92I-2002) e Jürgen Habermas (I929), dois dos autores mais influentes das últimas décadas no campo da filosofia moral e política, sejam fiéis - embora com modificaçóes importantes - ao espírito kantiano e liberal. Principais expoentes do que Chantal Mouffe chama de "democracia deliberativa", ambos postulam a recuperação da dimensão moral da democracia liberal como forma de combater a crise de legitimidade enfrentada pelo Estado nas últimas décadas e acreditam na possibilidade de conciliar as chamadas "liberdades dos antigos" com as "liberdades dos modernos", ligando internamente o princípio da soberania popular aos valores liberais (Moufre, 2000, pp. 80-83).

Neste artigo, discutiremos as concepçóes de justiça de Rawls e Habermas, dando destaque para o debate travado entre os dois e para a crescente sensibilidade de ambos à questáo da linguagem e do caráter sempre problemático do "universal" e do "necessário". Por fim, veremos como a abordagem da "democracia agonística", delineada por Mouffe (op. cit.), e a transição para o modelo do "julgamento refletivo" (reflective judgment), proposta por Ferrara (1999), ajudam-nos a escapar de alguns problemas fundamentais nas teorias deontológicas de Rawls e Habermas. 


\section{JOHN RAWLS E A JUSTIÇA COMO EQUIDADE}

John Rawls é certamente o responsável pela mais influente teoria da justiça liberal do século XX. Suas duas principais obras, A Theory of Justice (I97I) e Political Liberalism (1993), já foram extensivamente comentadas e debatidas por pensadores de todas as correntes ideológicas, desde individualistas radicais, como Nozick (1974) e Hayek (I960), até comunitaristas, como Michael Sandel (1984) e Charles Taylor (1994).

Veremos, em primeiro lugar, o pensamento original de $A$ Theory of Justice, para depois abordar as modificaçôes introduzidas em Political Liberalism, que são extensas o bastante e merecem consideração particular.

\section{A formulação original}

Como lembra Ferrara (op. cit., p. I3), Rawls parte de uma intuiçấo fundamental: a de que vivemos em sociedades complexas, nas quais náo se pode mais apelar a um conjunto de valores compartilhados para resolver os conflitos. Seu desafio, em $A$ Theory of Justice, portanto, é o de elaborar uma teoria sistemática da justiça de orientação kantiana, capaz de lidar com esse fato e de se apresentar como uma alternativa robusta contra as correntes intuicionista e, principalmente, utilitaristas.

A justiça como equidade rawlsiana retoma a tradição contratualista, substituindo o estado de natureza por uma "posição original", um experimento mental que nos dá as ferramentas para avaliar - em um equilíbrio refletivo (reflective equilibrium) (RAwLs, I97I, p. 20) - a estrutura básica da sociedade, concebida como uma empreitada cooperativa para obtenção de vantagens mútuas, marcada tanto pela identidade quanto pelo conflito de interesses (Ibidem, p. 4).

Assim, o problema dos princípios de justiça é precisamente o de achar princípios de validade geral que possibilitem uma distribuiçáo de direitos e deveres que possa ser racionalmente aceita por indivíduos caracterizados como pessoas morais e racionais, capazes de um senso de justiça e de formular determinada concepção do bem. Logo, se, para Rawls, a noçáo ética de bem (good) tem, nas sociedades contemporâneas, um conteúdo particular e específico, a noção moral de justo (right) é geral e passível de ser encontrada racionalmente, tendo, dessa forma, prioridade sobre a noção do bem, limitando, inclusive, a extensão dos interesses que podem ser perseguidos legitimamente.

A partir de sua concepção de sociedade, Rawls busca fazer os princípios de justiça a serem adotados resultado de um acordo original entre indivíduos livres e iguais, em uma situaçáo justa, de forma que uma sociedade bem organizada segundo esses princípios aproxime-se do ideal de uma associaçáo voluntária (Ibidem, p. I3), que não apenas dá subsídios para que seus membros levem adiante suas concepçôes particulares do bem, mas que também seja regulada por uma concepção pública de justiça (Ibidem, p. 4). 
O desenho da "posição original", entấo, deve obedecer a critérios que permitam que os princípios escolhidos estejam de acordo com essa concepçáo. Para isso, Rawls introduz diversas restriçôes: em primeiro lugar, embora os indivíduos representados na posiçáo original possuam autonomia completa, inclusive moral, as partes (parties) que efetivamente os representam possuem apenas o que Rawls chama de autonomia racional, ou seja, lançam mão apenas da razáo instrumental para fazer avançar os interesses dos representados, um ponto que, como veremos, foi bastante criticado por Habermas.

Além disso, a decisão sobre os princípios reguladores da estrutura básica da sociedade é tomada por debaixo de um "véu da ignorância", isto é, as partes envolvidas náo sabem qual será sua posiçấo na sociedade e nem sequer conhecem qual sua concepçáo específica do bem. Com isso, Rawls acredita poder deixar de lado todas as contingências sociais e naturais que separam e opóem os homens e guiam seus preconceitos (Ibidem, p. 19). O véu da ignorância é fundamental para a caracterização das partes como moralmente livres e iguais e, junto com a condição adicional de desinteresse mútuo, isto é, de que as partes não se interessam pelos interesses particulares dos demais , torna possível que a concepçáo de justiça seja escolhida de forma unânime; afinal, as partes são igualmente racionais e similarmente situadas, sendo convencidas pelos mesmos argumentos (Ibidem, p. 139).

O caráter racional-instrumental da deliberaçáo das partes envolvidas é garantido pela introdução do conceito de bens primários: mesmo sem conhecer a concepção ética específica defendida pelos indivíduos representados, as partes desejam maximizar sua fatia de bens primários - liberdades, renda, riqueza, entre outros -, essenciais para que consigam atingir seus objetivos.

A questáo da justiça, entáo, gira em torno da distribuiçáo desses bens primários, cujas prioridades relativas são especificadas nos dois princípios de justiça, que veremos logo a seguir. Antes, basta lembrar que náo apenas a influência kantiana é bastante transparente ao longo da argumentação de Rawls, mas também o próprio autor oferece, em um dado momento de $A$ Theory of Justice, o que ele chama de uma interpretaçáo kantiana da justiça como equidade, com base na noção de autonomia do homem como expressão de sua natureza livre e racional e na visão dos princípios de justiça acordados a partir da posiçáo original como imperativos categóricos kantianos (Ibidem, pp. 252-253).

Com esse desenho da posição original, Rawls defende, entáo, que a deliberaçáo das partes representantes chegaria a dois princípios básicos de justiça para a estrutura básica da sociedade, ordenados de forma lexicográfica. O primeiro princípio postula que cada pessoa deve ter um direito igual às mais extensivas liberdades básicas compatíveis com uma liberdade similar para os outros $^{2}$ (Ibidem, p. 60); o segundo, dividido em duas partes, afirma que as desigualdades

\footnotetext{
I É importante ressaltar aqui o papel da posição original como simples experimento mental, ou seja, a caracterização das partes como mutuamente desinteressadas náo significa, em absoluto, que os indivíduos representados sejam tomados como egoístas ou que não se importem com os interesses alheios (Ibidem, p. I47).

2 "As liberdades básicas são, em traços gerais, a liberdade política (o direito ao voto e a elegibilidade para cargos públi$\cos$ ), junto com a liberdade de expressão e de reunião; liberdade de consciência e de pensamento; liberdade da própria pessoa, junto com o direito de possuir propriedade (pessoal); e liberdade contra o encarceramento ou detenção arbitrá-
} 
econômicas e sociais devem ser reguladas de modo que: a) sirvam para o maior benefício dos menos privilegiados; e b) estejam ligadas a cargos e posiçôes abertos a todos, sob condiçóes de igualdade e oportunidade justas (Ibidem, p. 302).

Os princípios assim acordados diferem radicalmente das premissas utilitaristas, ao não admitirem que liberdades e direitos de indivíduos sejam sacrificados em nome da maximização da utilidade. Além disso, transformam as características da estrutura básica da sociedade de modo que o conjunto das instituiçóes não mais priorize valores tecnocráticos de eficiência (Ibidem, p. IOI), embora, naturalmente, o segundo princípio - o Princípio da Diferença - permita a existência de desigualdades, em função de considerações de eficiência, desde que essas desigualdades beneficiem principalmente os menos favorecidos.

Esse último ponto é particularmente importante, pois o Princípio da Diferença representa uma concepção fortemente igualitária, que toma a distribuição igualitária de bens primários como referência inicial e só permite desigualdades na medida em que elas melhorem a situação do grupo menos privilegiado.

Como veremos mais adiante, além de questionar traços constitutivos da posição original, muitos críticos também atacam o caráter hierárquico dos princípios escolhidos, com a priorização da "liberdade dos modernos", o que levou Rawls a reformular sua teoria em Political Liberalism e também no debate com Habermas, de forma a tentar mostrar a raiz comum tanto dos direitos liberais quanto do princípio de soberania popular.

É em $A$ Theory of Justice que o argumento de Rawls permanece mais próximo do que Ferrara (op. cit., p. 2) chama de modelo de "julgamento determinante". Para esse autor, a virada linguística ocorrida ao longo do século XX desencadeou na filosofia política e moral um processo - ainda longe de ser completado - de transiçáo de um paradigma de "julgamento determinante" para um de "julgamento refletivo".

Ferrara (op. cit.) acredita na possibilidade de esse novo padrão de julgamento ser capaz de evitar tanto as inconsistências insustentáveis do paradigma anterior quanto a sedução pós-moderna de renúncia a qualquer possibilidade de validade transcontextual e identifica, tanto em Rawls quanto em Habermas, traços fortes do modelo anterior, que, ao longo do desenvolvimento intelectual desses autores, foram atenuados e modificados em direção ao novo paradigma.

De modo geral, o modelo do julgamento determinante é o de um universalismo generalizante, centrado em princípios, em que um momento de necessidade é associado ao universal, que pode ser entendido conceitualmente de forma separada e a priori a qualquer manifestaçáo particular; por outro lado, o julgamento refletivo é fundamentado em um universalismo exemplar (exemplary universalism), em que só o particular está dado, e o universal deve ser achado a partir disso.

rios, da forma definida pelo conceito de império da lei. De acordo com o primeiro princípio, essas liberdades devem necessariamente ser iguais, uma vez que cidadáos de uma sociedade justa devem ter os mesmos direitos. O segundo princípio se aplica, em uma primeira aproximação, à distribuição de renda e riqueza e ao desenho de organizaçóes que fazem uso de diferenças em autoridades e responsabilidade ou cadeias de comando" (Ibidem, p. 6I, tradução própria). 
Para Ferrara (op. cit., p. 2), trata-se de um modelo de justiça em que um julgamento sobre ela, quanto a determinados assuntos locais, sob a ótica de um quadro normativo, é táo local e particular quanto os assuntos que esse quadro nos ajuda a avaliar. Em uma metáfora esclarecedora, Ferrara compara o modelo do julgamento determinante à execução de uma equaçáo algébrica, em que princípios formais permitem a subsunção do caso concreto sem problemas e geram resultados transcontextualmente válidos; já o julgamento refletivo aproximar-se-ia do paradigma estético, em que o simples fato de um artista seguir instruçôes definidas de determinado movimento não garante, em absoluto, a qualidade da obra, que, por sua vez, deve ser examinada a partir de suas próprias leis internas, que não podem ser reduzidas a princípios gerais abstratos.

Mais adiante, examinaremos os elementos do novo paradigma inseridos por Rawls em sua teoria; por enquanto, basta notar a forte proximidade do pensamento de Rawls com o paradigma do julgamento determinante e a observaçáo de Ferrara de que um dos motivos que o levaram a modificar sua teoria é interno a ela, estando relacionado à relação tensa que existe entre a justificação da justiça como equidade, com base no modelo do contrato, e a justificação com base em sua maior probabilidade de ser estabilizada com sucesso, uma vez que o véu da ignorância seja levantado.

Afinal, como pergunta Ferrara (op. cit., p. I7), se é possível estabelecer a superioridade da justiça como equidade, em termos práticos, para que precisaríamos da metáfora do contrato?

Para além disso, há outras críticas pertinentes que atingem pontos fracos da teoria rawlsiana. Fiel ao espírito do julgamento determinante, Rawls estabelece, em $A$ Theory of Justice, uma distinção muito radical entre o justo (right) e o bom (good), e, embora admita que alguma concepçáo do "bem" é necessária para que os princípios de justiça sejam elaborados, ele contorna isso com uma teoria "magra" do bem, que supóe, acerca das concepçóes "completas" do bem, apenas que elas têm certa estrutura racional (goodness as rationality) (RAWLS, I97I, p. 397).

Para Rawls, a concepção "completa" do bem surge apenas após a escolha dos princípios de justiça e é limitada por esses princípios. De todo modo, tal tratamento da relação entre questóes éticas e morais é bastante difícil de ser defendido. Sandel (op. cit.) critica com grande acuidade a aceitação de uma concepção essencialmente utilitária do "bem":

Se o "bem" [good] nada mais é do que a satisfaçáo indiscriminada de preferências dadas arbritrariamente, sem levar em conta o valor delas, então não é difícil imaginar que o "justo" [right] (...) deve ter maior importância. Mas, com efeito, o status moralmente rebaixado do bem acaba inevitavelmente pondo em xeque o status da justiça também. Uma vez que se admite que nossas concepçóes do bem são moralmente arbitrárias, torna-se difícil entender por que a maior das virtudes (sociais) deveria ser aquela que nos permite perseguir essas concepçôes arbitrárias "de modo táo completo quanto as circunstâncias permitirem” (Ibidem, p. I62, traduçáo própria). 
Outra objeção importante, de tom comunitarista, de Sandel contra Rawls gira em torno do alto preço a ser pago pela visão deontológica do self, independentemente de seus vínculos sociais. Para Sandel (op. cit., p. 172), nossas convicçóes e lealdades sáo elementos constitutivos de nossas identidades que garantem justamente nossa "profundidade moral":

Em seus próprios termos, o self deontológico, livre de todos os seus possíveis vínculos constitutivos, está menos emancipado do que desprovido de poder [disempowered]. (...) O que se passa por trás do véu de ignorância não é um contrato ou um acordo, mas uma espécie de descoberta (...). Para as partes na posição original (...) o momento emancipatório se desvanece antes mesmo de aparecer (Ibidem, pp. I70-I7I, tradução própria).

Por fim, vale observar outro viés de crítica à justiça como equidade, que pôe em questáo não seu caráter explicitamente individualista, mas sua aspiração a ser estritamente racional. Embora posteriormente tenha desistido dessa posiçáo, em $A$ Theory of Justice, Rawls apresenta sua teoria como parte importante - e talvez até mesmo a mais significativa - da teoria da escolha racional (RAWLS, I97I, p. 16).

Uma das críticas mais interessantes, nessa corrente, é a de Okin (1989), que retrabalha a ideia de racionalidade e benevolência em Rawls, ao tentar encontrar espaço, dentro da posiçáo original, para a inserção de uma perspectiva feminista. Para ela, a influência kantiana leva Rawls a formular sua teoria em termos racionalistas e sem espaço para sentimentos. No entanto, Okin vê brechas, dentro do pensamento de Rawls, que permitem a reinserçáo de uma dimensáo importante da vida moral. Embora Rawls passe longe da questáo da justiça intrafamiliar, sua ênfase na família enquanto instituiçáo fundamental para o desenvolvimento moral dos indivíduos é esclarecedora: para ele, a formaçáo saudável do senso moral na infância - momento em que aprendemos a adotar a perspectiva dos outros e pontos de vista diferentes - depende de amor, confiança, exemplo e orientação (RAWLS, I971, p. 466).

Assim, para Okin (op. cit., p. 238), temos, primeiro, uma tensão entre possíveis injustiças intrafamiliares (ignoradas por Rawls) e o fato de a família ser fundamental para a constituiçáo do senso de justiça da criança; em segundo lugar, há, igualmente, uma tensão entre o linguajar da "escolha racional" e a importância dos vínculos pessoais e dos sentimentos pelos outros, na formação moral da pessoa. Para a autora, as duas tensóes podem ser resolvidas com uma interpretaçáo alternativa da posiçáo original: deixando de lado a problemática interpretaçáo nos moldes da escolha racional ${ }^{3}$, seria mais frutífero entender a deliberação das partes não com base no desinteresse mútuo, mas sim na igual preocupação com todos. A posição original não seria uma abstração de todas as contingências da vida, mas sim um momento de identificação e cuidado igual com tudo aquilo que constitui os membros da sociedade.

3 Okin (op. cit., p. 242) escreve, de modo persuasivo, que, ao proibir as partes de ter qualquer conhecimento das probabilidades ou de suas próprias atitudes diante do risco, Rawls elimina decisivamente os modos de deliberação aos quais a teoria da ação racional tipicamente recorre, quando vigoram as condiçóes definidas anteriormente. 
Para Okin, a teoria rawlsiana seria:

interpretável de maneira mais coerente como uma estrutura moral fundada sobre a igual preocupação das pessoas umas com as outras, bem como por si próprias, uma teoria na qual a empatia e o cuidado pelos outros, bem como a consciência de suas diferenças, seriam componentes cruciais. (...) Pensar como uma pessoa na posiçấo original não significa agir como um ser desencarnado. Isso, como os críticos corretamente já apontaram, seria impossível. Trata-se de pensar a partir do ponto de vista de todos (Ibidem, p. 248, tradução própria).

Tal interpretaçáo afasta radicalmente a teoria rawlsiana do paradigma do julgamento determinante, aproximando-a de um universalismo exemplar típico do julgamento refletivo e tornando-a muito menos suscetível às críticas de Sandel, enumeradas anteriormente. Trata-se, entretanto, de uma interpretação bastante afastada da do próprio Rawls, que, por sua vez, modificou bastante, ao longo do tempo, sua teoria original, como veremos a seguir.

\section{Uma concepção política de justiça}

Se $A$ Theory of Justice e Political Liberalism marcam duas fases distintas importantes do pensamento de Rawls, há entre elas uma razoável fase de transição: a diminuição da importância da metáfora do contrato e a avaliaçáo dos princípios de justiça a partir de um contexto mais situado e específico - por oposição à generalizaçáo "a-histórica" - marcam, talvez, os dois pontos de inflexão fundamentais desse período intermediário, bem como a introdução do conceito de "razoável", que desempenha papel de destaque em Political Liberalism. Nessa obra, Rawls procura consertar o que seria uma aparente incompatibilidade entre o pluralismo de valores e a visão de A Theory of Justice, ao reformular sua proposta, nos termos de uma concepçáo especificamente política de justiça, e não de uma doutrina moral abrangente (comprehensive doctrine).

Uma concepçáo política de justiça é, de acordo com Rawls, necessária a partir do momento em que o liberalismo político assume o pluralismo razoável de valores como um resultado normal do exercício da razão humana, o que origina o problema de qual a concepção de justiça apropriada para indivíduos que habitam universos éticos diversos (FerRarA, op. cit., p. I9).

A afirmação do caráter político de uma concepçáo de justiça implica, segundo Rawls, três coisas: a) que ela deve ser aplicada, como um esquema básico de cooperação social entre indivíduos livres, à estrutura básica da sociedade, com suas principais instituiçóes políticas, econômicas e sociais; b) que tal concepção deve ser apresentada de forma independente de quaisquer doutrinas filosóficas ou religiosas mais abrangentes ${ }^{4}$ (embora deva, posteriormente, ser passível de ser

\footnotetext{
4 Nas palavras de Rawls, "a distinçáo entre uma concepção política de justiça e outras concepçôes morais é uma questáo de escopo (...). Uma concepção moral é geral se se aplica a uma vasta gama de assuntos, e, no limite, a todos os assuntos universalmente. Ela é abrangente quando inclui concepçôes acerca do que deve ser valorizado na vida
} 
encaixada como um "módulo" dentro dessas concepçóes); e c) que ela deve ser elaborada em termos de ideias políticas fundamentais existentes na cultura política pública de uma sociedade democrática (RAwLS, 1993, p. 223).

O último ponto deixa muito claro o aspecto contingente e situado dessa nova concepçáo rawlsiana, introduzindo, nas palavras de Ferrara (op. cit., p. 2I), um "momento hegeliano" indicado pela necessidade de começar a busca por uma concepção política de justiça a partir do mergulho nas tradiçóes da própria sociedade - em um quadro de referência antes puramente kantiano; tal "momento hegeliano", por sinal, é reforçado por uma nova concepção temporal da argumentaçáo de Rawls, em que são identificados dois estágios da emergência de tal concepçáo de justiça: em um primeiro momento, as partes aceitariam as intuiçóes da justiça como equidade como uma soluçáo de compromisso capaz de formar um consenso constitucional-procedimental, e, em um estágio mais avançado, a necessidade constitucional de diálogo promoveria a apariçấo de um overlapping consensus de cunho moral.

Em paralelo, Rawls também adota uma nova estratégia argumentativa em Political Liberalism. Se grande parte de $A$ Theory of Justice era dedicada a mostrar a justiça como equidade como uma concepçáo mais sofisticada e apropriada do que a utilitária, agora Rawls passa a se esforçar mais por mostrar como sua teoria é uma versão particularmente igualitária do liberalismo político, que, por sua vez, é plenamente compatível com a multiplicidade de doutrinas abrangentes existentes.

Para diversos críticos, inclusive para Habermas, tal postura implica um viés que poderíamos chamar de conservador, por colocar ainda mais em seu centro os direitos liberais, deixando um pouco de lado a questáo da soberania popular.

Rawls, contudo, como veremos, nega tais acusaçôes. De todo modo, ele admite que, entre outros motivos, como a discussão acerca das liberdades básicas tende a ser mais consensual do que aquela acerca da regulamentação das desigualdades sociais e econômicas, só as primeiras fazem parte do "essencial da constituiçáo". Com efeito, em virtude da mudança teórica de rumo, a preocupaçáo com a questão da redistribuição de bens materiais e a defesa do Princípio da Diferença perdem certa importância em Political Liberalism.

Por outro lado, Rawls reafirma sua concepçáo de sociedade como um sistema de cooperação entre homens livres e iguais e trata esses homens como não apenas racionais, mas também razoáveis, isto é, dotados de uma sensibilidade moral que os impele a buscar um modo justo de cooperaçãos.

humana, ideais de caráter pessoal, bem como ideais sobre amizades e relaçóes familiares e associativas, e tudo o mais que informa nossa conduta e, no limite, nossa vida como um todo. Uma concepçáo é totalmente abrangente se cobre todos os valores e virtudes reconhecidos dentro de um sistema precisamente articulado" (RAWLS, I993, p. I60, tradução própria). Para Rawls, o fato de que, em geral, os indivíduos não encaram suas doutrinas (morais, filosóficas ou religiosas) como totalmente gerais e abrangentes abre uma brecha que possibilita a formulação de princípios de justiça que podem ser apresentados como freestanding e, ao mesmo tempo, serem coerentes com essas doutrinas abrangentes. 5 "Agentes apenas razoáveis não teriam fins próprios que gostariam de alcançar através da cooperação justa; agentes apenas racionais não têm um senso de justiça e não conseguem reconhecer a validade independentemente das pretensôes [claims] dos outros" (RaWLs, I993, p. 52, tradução própria). 
Com isso, os princípios de justiça a serem decididos, por sua própria natureza estritamente política, devem ser passíveis de serem defendidos publicamente, sem qualquer referência direta a doutrinas éticas abrangentes. A deliberação pública deve situar-se dentro do reino da razáo pública, isto é, aquele tipo de razão comum a todos os que partilham o status de cidadáos com direitos iguais e que, por meio da obrigação de civilidade, se veem instados a justificar a base de suas açôes e opiniôes, diante de seus concidadáos, em termos que possam ser efetivamente aceitos pelos demais como consistentes com sua liberdade e igualdade (RAWLS, I993, p. 2I8).

O universo da razão pública, como bem observa Ferrara (op. cit., p. 24), não é o mesmo que o consenso sobreposto, possuindo a característica dinâmica de gerar novos consensos, não sendo mero registro das convergências preexistentes.

Assim, para Rawls, a justiça como equidade e, de modo geral, o liberalismo político se apresentam como a soluçáo encontrada por pessoas livres, dotadas dos dois poderes morais (capacidade de um senso de justiça e de uma concepção do bem), que vivem em universos éticos diversos e mergulham na tradição democrática de sua sociedade, para achar, em um equilíbrio refletivo, princípios de justiça que garantam a existência da sociedade como um sistema de cooperação e reciprocidade.

A utilização da razão pública para a obtenção de uma interpretação compartilhada acerca da distribuiçáo dos direitos e liberdades faz emergir um consenso sobreposto de cunho moral que assegura a unidade social sem desrespeitar o pluralismo ético. Se, com essa nova formulação, Rawls evita o tom excessivamente racionalista que permeia $A$ Theory of Justice e, com o conceito de razão pública, introduz uma nova compreensão, mais contextualizada e menos fixada em princípios generalizáveis, por outro lado, há uma dificuldade central em sua teoria, representada pelo caráter essencialmente antipolítico que ele dá à sua concepção de política.

Como escreve Ferrara (op. cit., p. 22), o aspecto "político" de uma concepção de justiça para Rawls está em sua capacidade de transcender as divisōes existentes na sociedade, isto é, de ser passível de aceitaçáo unânime, indo de encontro à concepçáo da política como terreno de disputas intermináveis entre diversos grupos. Parece bem claro que isso deriva, ao menos em parte, da distinçáo ainda grande - embora mais matizada - que Rawls traça entre os conceitos de justo (geral) e de bom (particular).

Se a concepção de justiça é política, entấo, o reino do político deve necessariamente absorver essa generalidade do justo, o que implica toda uma série de problemas, em especial, a questáo das fronteiras entre os conceitos e suas inter-relaçóes.

Em primeiro lugar:

Uma concepção política de justiça deve ser independente de ideias sobre a natureza humana, sobre a racionalidade e de valores (...) que são parte de doutrinas abrangentes não compartilhadas por todos os cidadáos. Por outro lado, no entanto, uma concepção política de justiça não é uma construção abstrata. Seus princípios devem se apoiar em ideias que pertençam à cultura pública de uma sociedade democrática. Algumas dessas 
ideias são: a concepção de um modelo de pessoa provido de uma capacidade para um senso de justiça e de uma capacidade para uma concepçâo do "bem" [good] (...). Contudo, onde se dá a separação entre as chamadas concepçoos abrangentes e ideias tão gerais quanto essas? Na falta de um critério substantivo, a distinção (...) parece depender totalmente na extensão contingente do consenso realmente existente em uma dada crença ou valor - com consequências relativistas que se refletem no resto da teoria (FERRARA, op. cit., pp. 32-33, tradução própria).

Mais ainda:

Relacionada a esse ponto está a pressuposição de Rawls de que as fronteiras do político - dada sua definição do termo "político" - estão elas próprias acima de controvérsia (...). [Mas] as fronteiras do político não parecem estar na fronteira da política; ao contrário, elas estão metaforicamente no centro da política, no sentido de que elas constituem um dos principais temas do debate político e frequentemente são contestadas (FERRARA, op. cit., p. 33, tradução própria).

Em outras palavras, a tensão entre os elementos novos contextuais e o modelo antigo, próximo do julgamento determinante, com uma separação ainda rígida entre o justo e o bom e a crença na possibilidade de separação entre o universal e o particular, cria grandes problemas internos à teoria rawlsiana. A necessidade de chegar a princípios generalizáveis de justiça e a subsequente definição do "político" como um terreno do consenso tornam a teoria proposta por Rawls refém das contingências sociais, isto é, das relações de hegemonia engendradas pelas relaçóes de poder existentes.

Nesse sentido, parece lícito, de fato, identificar uma guinada conservadora no pensamento de Rawls, surgida, curiosamente, como uma reaçáo náo apenas às críticas liberais radicais, mas também às críticas de tom comunitarista.

\section{JÜRGEN HABERMAS E O MODELO DISCURSIVO DE DEMOCRACIA}

Autor de uma vasta obra de caráter multidisciplinar, Jürgen Habermas é certamente um dos maiores e mais ambiciosos intelectuais do século XX. Ex-assistente de Adorno e herdeiro intelectual da Escola de Frankfurt, Habermas manteve, ao longo de sua carreira, o impulso crítico com vistas à emancipaçáo, mas retrabalhando-o dentro de um paradigma comunicacional capaz de reintroduzir a bidimensionalidade da razão dentro da teoria crítica e evitar o beco sem saída teórica atingido por Adorno, Horkheimer e Marcuse, com seu diagnóstico da universalidade da reificação.

Dado o escopo de sua obra, passaremos aqui por dois momentos particulares do trabalho de Habermas; em primeiro lugar, abordaremos os fundamentos de sua teoria social, tal como 
desenvolvidos em A Teoria do Agir Comunicativo, e, em seguida, examinaremos os insights no campo da filosofia política presentes em Facticidade e Validade.

Como veremos, Habermas se afasta radicalmente de seus predecessores da Escola de Frankfurt por sua posição política reformista, que leva a sério a tradiçẫo da democracia burguesa.

\section{Mundo da vida e sistema}

Pode-se dizer que, em A Teoria do Agir Comunicativo, Habermas conseguiu sintetizar intuiçóes presentes anteriormente em um arcabouço teórico ambicioso, que representou uma defesa da razão e do projeto iluminista contra a concepção frankfurtiana de reduçáo da razão à reificaçáo.

Em relação à trajetória intelectual de Habermas, vale lembrar que esse livro é posterior à chamada "virada procedimental linguística em direção à ação", ocorrida ao longo dos anos 70 e a partir da qual Habermas adotou em definitivo o paradigma da filosofia da linguagem e um ponto de vista crítico quase transcendental - pois inerente às próprias condiçóes e pressupostos da comunicação -, por oposição à crítica histórica imanente tipicamente marxista.

É com tal virada linguística que Habermas elabora a intuiçâo fundamental de que o consenso é o telos da linguagem e de que a intercompreensão depende do reconhecimento - que pode ser racional - das pretensóes de validade (validity claims) emitidas pelos atores envolvidos em um ato comunicativo. Em outras palavras, a estrutura mesma dos atos de linguagem contém a antecipação de uma forma de vida comunicativa e democrática, fornecendo, assim, um fundamento normativo essencial para a teoria crítica.

Em A Teoria da Ação Comunicativa, Habermas leva tais intuiçôes adiante, ao mesmo tempo em que tenta elaborar uma teoria social robusta capaz de interpretar criticamente a realidade social contemporânea. Um de seus primeiros passos é o desenvolvimento de um modelo comunicativo de ação a partir da crítica às limitaçôes e do exame da racionalidade do modelo teleológico da açáo (associado à teoria da escolha racional), do modelo da açáo regulada normativamente (associado a Durkheim e Parsons) e do modelo da ação dramatúrgica (tipicamente goffmaniana). Com isso, Habermas chega à ação comunicativa, que considera todas as funçóes da linguagem e mantém sua reflexividade:

Para o modelo da ação comunicativa, a linguagem é relevante somente do ponto de vista pragmático de que aqueles que falam, ao empregar frases orientadas para o entendimento, assumem relações com o mundo, não apenas de forma direta como nas açóes teleológicas, normativamente reguladas ou dramatúrgicas, mas também de maneira reflexiva. Aqueles que falam integram os três mundos formais [formal world-concepts] (...) em um sistema e pressupóem esse sistema em comum como um quadro interpretativo dentro do qual se pode alcançar o entendimento. Eles não mais se relacionam de forma imediata com algo nos mundos objetivo, social ou subjetivo; em vez disso, eles 
relativizam suas falas contra a possibilidade de que sua validade pode ser contestada por outros atores (HABERMAS, I987a, pp. 98-99, tradução própria).

$\mathrm{O}$ apelo a pretensốes de validade está intimamente ligado ao potencial de racionalidade da comunicação, pois cada ato de linguagem traz em si uma alegaçáo de validade em cada um dos três níveis mencionados - relaçáo com o mundo objetivo, relaçáo com o contexto normativo e relação com a experiência subjetiva -, que pode ser racionalmente criticada, na medida em que os participantes negociam uma definição da situação $0^{6}$.

Um ponto importante para Habermas é que a ordem negociada com sucesso na ação comunicativa demanda a incorporaçáo do ponto de vista do outro. Além disso, é preciso clarificar que o modelo da ação comunicativa não iguala a açáo à comunicação; os atores que negociam o consenso pela linguagem estáo sempre perseguindo seus fins particulares, o que mantém uma estrutura teleológica comum a todos os conceitos de ação. O que distingue a ação comunicativa é a forma como as açôes dos atores são coordenadas.

$\mathrm{Na}$ ação puramente estratégico-teleológica, que, a rigor, é apenas um caso limite do modelo proposto por Habermas, temos apenas planos de açáo concebidos de forma monológica pelos participantes e realizados sob a égide do cálculo egocêntrico; na ação comunicativa tout court, temos um processo dialógico de intercompreensáo entre atores que buscam um consenso racionalmente motivado para coordenar suas ações.

Da definição formal da açáo comunicativa, segue o conceito de "mundo da vida". Como o autor deixa claro, todos os processos de intercompreensão são realizados contra o pano de fundo de um estoque de conhecimento culturalmente adquirido que, como um todo, permanece náo problemático, mas cujas "regióes específicas" são tematizadas pelos participantes da interação (Habermas, I987a, p. IOo). Em outras palavras, apenas o segmento do mundo da vida incluído na situaçáo de açáo pode ser problematizado, enquanto o mundo da vida qua mundo da vida permanece sempre como um pano de fundo, um horizonte de conhecimentos pré-interpretados e pressuposiçôes culturais, dentro do qual os atores navegam sem poder "sair":

O "mundo da vida" filtrado para fora do domínio de relevância de uma situação de açáo permanece aberto como uma realidade que é ao mesmo tempo inquestionável e vaga. (...) É só quando se torna relevante para uma situação que um segmento do "mundo da vida" pode vir à tona como algo que é culturalmente aceito, que se baseia em interpretaçóes, e que, agora que pode ser tematizado, perde esse caráter "dado" inquestionável [unquestionable givenness] (HABERMAS, 1987b, p. I32, traduçáo própria).

6 Nas palavras de Habermas (I987a, p. 99, tradução própria): "Assim, o sujeito que fala pretende a verdade para afirmaçōes ou suposiçōes existenciais, justiça para açóes legitimamente reguladas e seu contexto normativo e sinceridade para a manifestação de experiências subjetivas. Podemos facilmente reconhecer aí as três relaçóes do ator com o mundo pressupostas pelos cientistas sociais nos conceitos de ação previamente analisados; mas, no conceito da ação comunicativa, elas são atribuídas à perspectiva dos próprios atores envolvidos na comunicação". 
Como locus da reprodução simbólica, o mundo da vida é, ao mesmo tempo, o meio e o resultado do agir comunicativo. Seus três componentes estruturais são a cultura, a sociedade e a personalidade, cujos papéis principais ${ }^{7}$ nos processos reprodutivos são, respectivamente, o do estabelecimento de esquemas interpretativos adequados ao consenso, relaçóes interpessoais legitimamente ordenadas e capacidades interativas (identidade pessoal) (Ibidem, p. I42).

A teoria da evoluçáo habermasiana aponta para a racionalização do mundo da vida como o processo de diferenciaçấo dos componentes estruturais desse que enseja uma autonomia crescente dos atores, na medida em que os processos de intercompreensão passam a se desligar de contextos normativos tradicionais e se tornam racionalmente motivados.

Antes de vermos a (problemática) passagem da racionalização contrafactual do mundo da vida à sua racionalização real, é preciso, contudo, examinar um segundo nível da realidade social, sublinhado por Habermas. Isso porque, tomando emprestada a distinção de Lockwood (1964) entre integração social e integração sistêmica, Habermas vê a identificaçăo total da sociedade com o mundo da vida como um erro típico do idealismo hermenêutico .

Para ele, é preciso lançar mão do conceito luhmanniano de sistema: sob esse ângulo, o mundo da vida vira mais um entre vários sistemas autorregulados de interconexóes de açáo funcionalmente estabilizadas. Se a teoria da ação nos dá acesso à perspectiva dos participantes e da integraçáo social, a teoria dos sistemas nos fornece a perspectiva externa do observador e da integração sistêmica. Como cada uma das duas, por si só, é necessariamente limitada, Habermas propôe a aliança das duas estratégias conceituais, a partir da noção inicial das sociedades como "systemically stabilized complexes of action of socially integrated groups" (HABERMAS, I987b, p. 152).

Com isso, podemos descrever a evolução social para Habermas náo apenas como um processo de diferenciação interna do mundo da vida - em que o potencial de racionalidade é liberado - e dos sistemas - em que o potencial adaptativo é liberado -, mas também como um processo de diferenciação entre os dois (Ibidem, p. I53).

Tal processo não é meramente contrafactual, pois Habermas o projeta mesmo na história real. Com o advento do capitalismo e com a institucionalizaçáo das mídias reguladoras do poder e do dinheiro, os subsistemas acoplados da economia e do Estado se liberaram dos contextos do mundo da vida e se autonomizaram, fazendo a disjunçáo entre sistema e mundo da vida, antes puramente analítico-metodológica, tornar-se uma realidade histórica. A partir daí, esses subsistemas não mais precisam apelar à ação comunicativa para a coordenação das açôes, o que, por si só, não é algo necessariamente negativo para Habermas, pois se trata de um processo indispensável em função da crescente complexidade social.

7 Habermas, contudo, especifica que cada componente estrutural do mundo da vida também colabora para a reprodução dos demais, ou seja, os esquemas interpretativos que perfazem os processos de reproduçáo cultural também auxiliam na integraçáo social e na socialização, e assim por diante.

8 Como lembra Vandenberghe (1998, p. 275), o recurso à teoria dos sistemas se dá justamente porque os efeitos latentes da reprodução material do mundo da vida que são integrados sistemicamente não podem ser compreendidos de maneira adequada, dentro da perspectiva do mundo da vida. Uma "objetivaçáo" ou "reificaçáo" metodológica do mundo da vida é, portanto, necessária. 
$\mathrm{Na}$ medida em que as funçóes de reprodução material não precisam ser necessariamente preenchidas pela ação comunicativa, elas podem ser coordenadas por açôes mediatizadas sem consequências patológicas. Esse ponto, por sinal, deixa clara a distinçáo básica entre trabalho e interação, já presente há bastante tempo na obra de Habermas e que se afasta muito da perspectiva marxista, ao reduzir o trabalho à açáo instrumental, retirando do trabalho, portanto, todos os aspectos cognitivos, normativos e expressivos que contém nos escritos do jovem Marx.

De todo modo, na visão habermasiana, as consequências patológicas aparecem apenas quando os subsistemas autônomos passam a "colonizar" o mundo da vida, interferindo nas funçôes de reprodução simbólica. Se as mídias reguladoras anônimas e impessoais, como o dinheiro e o poder, penetram nas fronteiras do mundo da vida, "desverbalizando" as interaçôes, temos, entáo, como consequência, a reificação das relaçôes sociais, na medida em que a intercompreensáo fundamentada na negociaçáo das pretensôes de validade é interrompida e os atores se veem obrigados a adotar uma atitude objetivante a respeito deles mesmos e dos outros, o que implica que as relaçóes sociais e as experiências vividas acabam sendo sistematicamente assimiladas às coisas, ou seja, instrumentalizáveis e manipuláveis.

As interaçóes mediatizadas possibilitam aos atores coordenar suas açôes sem passar por uma definição comum da situação. A invasão do agir mediatizado e dos imperativos sistêmicos dentro da reprodução simbólica do mundo da vida é particularmente danosa, porque, ao contrário mesmo do agir estratégico, não é motivada racionalmente por motivos, mas empiricamente por sançóes e gratificaçóes.

Em resumo, essa é a tese da colonização do mundo da vida pelos subsistemas, o diagnóstico habermasiano da realidade contemporânea. Por um lado, sua empreitada foi muito bem-sucedida se considerarmos o monumental esforço de síntese na elaboraçáo de uma teoria social sólida para fundamentar um diagnóstico crítico, direcionado à emancipaçáo, capaz de evitar o pessimismo irreversível que vê apenas processos de reificação em ação. Com o recurso à crítica quase-transcendental a partir das próprias condiçôes de possibilidade da comunicação, Habermas consegue produzir um arcabouço teórico em que a reificação aparece náo apenas como um processo reversível, mas, principalmente, a própria razáo comunicativa, entendida por meio da pragmática universal, apresenta, dentro de si, um momento crítico que não pode jamais ser plenamente silenciado.

Com isso, Habermas combate o predomínio coisificante da razão instrumental, sem precisar apelar para o irracionalismo ou para uma abordagem puramente estética da vida. Por outro lado, não se pode ignorar alguns problemas centrais. Sob diversos pontos de vista, o aspecto mais problemático é a maneira aparentemente unilateral como Habermas separa, de um lado, o agir comunicativo e o mundo da vida e, de outro, o agir mediatizado e os subsistemas autônomos que seriam desprovidos de normas.

Problemático porque, em primeiro lugar, fundamenta-se em uma reificação das categorias analíticas e em uma idealização do mundo da vida, sugerindo que neste só há o agir comunicativo, enquanto no sistema há apenas a ação teleológica; para Vandenberghe (op. cit., p. 277), 
Habermas confunde a racionalização do mundo da vida com sua reprodução simbólica. Enquanto a primeira demanda, necessariamente, a presença da ação comunicativa, a segunda também ocorre por meio da ação estratégica dissimulada (agir strategique masque).

Em última instância, é preciso não perder de vista a perspectiva foucaultiana e bourdieusiana de que a reprodução do mundo da vida também é levada a cabo pelo uso perlocucionário da linguagem, com uma grande dose de violência simbólica que deforma gravemente a comunicaçáo.

Como lembra Vandenberghe (op. cit., pp. 270-27I), Habermas chega posteriormente a se retratar, precisando que, embora o mundo da vida seja integrado socialmente em primeira instância, ele náo está isento nem do poder nem do agir estratégico; de todo modo, tal reconhecimento não muda o fato de que a temática foucaultiana do papel do poder na vida cotidiana tem uma importância secundária, uma vez que seu foco está na colonização do mundo da vida pelo sistema.

Além disso, o outro lado desse problema central também merece destaque, já que as dicotomias comunicação x agir mediatizado e mundo da vida x sistema também levam à conclusáo insustentável de que a integração sistêmica ocorre de forma absolutamente não normativa.

Temos, aqui, o outro lado da moeda: tampouco se pode afirmar que a reproduçáo material e sistêmica resulta de processos puramente instrumentais. Trata-se, no mínimo, de uma formulaçáo infeliz. Não por acaso, aliás, temos, no campo da Sociologia econômica, uma longa série de autores que, a partir do artigo de Granovetter (1985), lançaram mão de diversas estratégicas metodológicas e teóricas para demonstrar o "enraizamento" (embeddedness) - ou, ao menos, a imbricação mútua - da economia nas relações sociais.

Parte do problema de Habermas em lidar com essas questôes talvez possa ser atribuído ao fato de que nosso autor náo possui um conceito mediador como o habitus, de Bourdieu, ou as situated practices, de Giddens, para verdadeiramente superar o dualismo entre mundo da vida e sistema.

De todo modo, munidos desse arcabouço teórico, podemos passar agora à Facticidade e Validade, obra em que Habermas adota uma posiçấo mais agressiva e positiva, propondo um modelo de democratizaçáo radical da sociedade.

\section{A natureza dupla do Direito}

Uma espécie de "posfácio político à Teoria do Agir Comunicativo" (VAndenberghe, op. cit., p. 285), Facticidade e Validade representa a tentativa habermasiana de propor um modelo positivo de democracia radical que recupera argumentos já esposados anteriormente pelo autor.

Utilizando como base seu conceito de agir comunicativo, Habermas faz uma crítica tanto da teoria econômica da democracia, desenvolvida a partir dos pressupostos do individualismo metodológico, quanto do cinismo da teoria dos sistemas, que destrói o conteúdo normativo da democracia (HABERMAS, 1997, p. 6I).

Sua proposta é uma defesa de um projeto republicano capaz de afirmar a co-originalidade tanto da soberania popular quanto dos direitos individuais liberais, a partir de uma perspectiva 
em que a legitimidade do poder político do Estado depende, em última instância, do poder comunicativo da sociedade civil.

Em relação à Teoria do Agir Comunicativo, Habermas introduz uma novidade importante que garante a mudança de ênfase da disjunção entre sistema e mundo da vida para o "reacoplamento" entre ambos: isso ocorre porque, em Facticidade e Validade, o Direito é interpretado como um sistema de ação misto que assegura a mediaçáo entre sistema e mundo da vida e que funciona como um canal de transmissáo do poder comunicativo para dentro do sistema. Assim, a compreensão da função integrativa do Direito nas sociedades modernas exige o reconhecimento destes dois momentos, isto é, do duplo pertencimento do Direito tanto ao reino dos "fatos" quanto ao das "normas".

Para Habermas, o não reconhecimento dessa natureza dupla do Direito resulta em abordagens unilaterais, como resume Ferrara:

Por um lado, existem abordagens sociológicas do Direito que enfatizam sua positividade e não dão importância à sua dimensão normativa. Elas podem dar conta dos efeitos empíricos do funcionamento do sistema legal como um sistema autônomo, mas não podem explicar sua função integrativa. Por outro lado, existem teorias normativas da justiça e do direito que ignoram a dimensáo social e positiva do sistema legal e, assim, permanecem em um nível abstrato. Luhmann e Rawls encarnam essas duas formas de unilateralidade que Habermas tenta superar (FERRARA, op. cit., p. 49, traduçáo própria).

Logo, do ponto de vista da facticidade, o Direito moderno aparece como um sistema de leis restritivas e impostas, que regula a margem de manobra dos atores estratégicos e cumpre funçóes de integração em uma sociedade complexa, em que tais funçôes não mais podem ser levadas a cabo com base em um horizonte de valores compartilhados. Por outro lado, do ponto de vista de sua força normativa, o Direito moderno náo mais pode se amparar em visóes de mundo religiosas, devendo, portanto, derivar sua legitimidade do princípio de soberania popular, ou seja, da formaçáo discursiva da opiniáo e da vontade.

Surge, entâo, a questão dupla de: a) garantir a existência de uma esfera pública ${ }^{9}$ vibrante, em que as construçốes discursivas possam se formar de maneira livre; e b) assegurar a capacidade de

9 "Esfera ou espaço público é um fenômeno social elementar, do mesmo modo que a ação, o ator, o grupo ou a coletividade; porém ele náo é arrolado entre os conceitos tradicionais elaborados para descrever a ordem social. A esfera pública náo pode ser entendida como uma instituição, nem como uma organizaçăo, pois ela não constitui uma estrutura normativa capaz de diferenciar entre competências e papéis, nem regula o modo de pertença a uma organizaçáo, etc. Tampouco ela constitui um sistema (...) A esfera pública pode ser descrita como uma rede adequada para a comunicaçáo de conteúdos, tomadas de posição e opinióes; nela os fluxos comunicacionais sáo filtrados e sintetizados, a ponto de se condensarem em opiniôes públicas enfeixadas em temas específicos. Do mesmo modo que o mundo da vida tomado globalmente, a esfera pública se reproduz através do agir comunicativo, implicando apenas o domínio de uma linguagem natural; ela está em sintonia com a compreensibilidade geral da prática comunicativa cotidiana" (HABERMAS, 1997, p. 92). 
influência dessa esfera pública sobre os subsistemas institucionalizados, isto é, dos mecanismos que possibilitem que os fluxos comunicativos se transformem em poder administrativo.

Entre as duas questôes está o ponto crucial da co-originalidade do princípio da soberania popular e dos direitos individuais liberais; afinal, estes últimos estáo contidos nos pressupostos da ideal speech situation, que cria a possibilidade de um processo racional de deliberação e legislaçãa ${ }^{\text {to }}$ :

Do seu ponto de vista, a tensão entre a ideia liberal dos direitos do homem e a ideia republicana da vontade popular pode ser superada se o princípio da democracia é revinculado ao princípio da discussão, (...) que estipula que somente são legítimas as normas de ação que poderiam conseguir o consentimento de todos aqueles a que dizem respeito se uma discussão racional tivesse sido levada a cabo. Desde que o princípio democrático seja revisado ao plano procedimental de tal maneira que a legitimidade de uma decisão (...) resulte da deliberaçáo de todos, fica claro que a ideia (liberal) da autodeterminação do sujeito e a ideia (republicana) da autorrealização do povo não mais se opóem, mas se pressupóem. (...) Ora, se a legitimidade do direito depende, em última instância, da formação discursiva da opiniáo e da vontade políticas, então, é preciso garantir juridicamente a participação de cada um no processo legislativo e institucionalizar os princípios da democracia liberal. É aqui que intervém a ideia de Estado de Direito democrático e social que garante constitucionalmente os direitos fundamentais liberais (...) e democráticos (...), assim como, por consequência, os direitos sociais que devem assegurar as condiçôes materiais mínimas necessárias para o exercício dos direitos fundamentais de autonomia privada e pública (VANDENBERGHE, op. cit., pp. 286-287, traduçáo própria).

No entanto, duas observaçóes importantes ainda precisam ser feitas sobre o projeto democrático habermasiano e seu uso da ideia de esfera pública. Em primeiro lugar, trata-se de um projeto radical, mas limitado: o sentido da esfera pública é garantir a legitimidade e, ao mesmo tempo, pressionar a esfera legislativo-administrativa; a deliberação e a opinião pública devem tematizar problemas, imaginar soluçóes e erguer-se em espaço de resistência contra a colonização do mundo da vida pelos sistemas, mas elas jamais governam por si mesmas, já que, como vimos anteriormente, nenhuma sociedade complexa pode ser reduzida completamente apenas à dimensão comunicativa do mundo da vida. O que está ao alcance de tais fluxos comunicativos é a possibilidade de mobilizar o "poder comunicativo gerador da democracia contra a autonomizaçáo ilegítima do poder social e administrativo" (VANDENBeRGHe, op. cit., p. 292).

Em segundo lugar, a comparação das distintas concepçôes de democracia deliberativa e pluralismo em Rawls e Habermas ilustra muito bem a forma como o segundo evita com

io Disso decorre a afirmação de Ferrara de que Habermas deriva um sistema de direitos dos pressupostos da razáo comunicativa e de que a substância dos direitos humanos reside nas condiçóes formais de institucionalização legal dos processos discursivos de formaçáo da opiniáo e da vontade, por meio dos quais a soberania popular exerce sua autoridade (FERrara, op. cit., pp. 46 e 52 ). 
habilidade os problemas teóricos enfrentados pelo primeiro. Como vimos, Rawls esposa uma concepçáo problematicamente antipolítica da política, em que a razáo pública está restrita a temas já reconhecidos como públicos, o que resulta náo apenas na exclusão dos tópicos controversos como também na reificaçâo da fronteira que separa o público e o privado.

Além disso, para Rawls, o locus da razão pública é constituído pelas principais instituiçōes da sociedade política, por oposição à esfera pública habermasiana (FerRARA, op. cit., p. 64).

Em Habermas, por sua vez, não há a menor necessidade de uma restrição voluntária de temas:

A abordagem de Habermas (...) se baseia em uma visão muito mais otimista da razão pública ou dialógica. Não há nada como uma questão "intratável". Todos os temas, incluindo valores, (...) são abordáveis em discussóes públicas e devem ser trazidos à esfera pública se alguém assim desejar. (...) A abordagem de Habermas para a questáo do pluralismo parece mais capaz que a de Rawls de dar conta do fato de o terreno comum sobre o qual um consenso sobreposto [overlapping consensus] pode crescer não é algo que é dado e que só pode ser protegido através da restrição da discussão pública a certos tópicos, mas sim algo que, com o passar do tempo e a mudança nos contextos, pode também se reduzir ou até desaparecer (FerRARA, op. cit., pp. 65-66, tradução própria).

Por fim, é preciso lembrar apenas que, para Ferrara, mesmo tais pontos positivos da teoria habermasiana - cuja versão apresentada em Facticidade e Validade marcaria o ponto de chegada de uma lenta transiçáo do modelo do julgamento determinante em direçáo ao julgamento refletivo - náo apagam completamente os traços ainda marcantes do paradigma anterior, como a disjunção ainda excessivamente forte entre moral e ética, que não considera, por exemplo, o fato de que nossas chances de chegar a um acordo sobre o que é justo depende das modificaçóes sofridas por nossas concepçôes do que é bom, o que, por sua vez, implica que a justiça não pode ser considerada independentemente do bem, da maneira postulada por Habermas (FerRara, op. cit., p. 163).

\section{O DEBATE RAWLS-HABERMAS}

Em 1995, nas páginas do Journal of Philosophy, Habermas e Rawls travaram um debate essencial para a melhor compreensão das teorias de ambos. Nesse contexto, é bastante significativo que Habermas tenha, de imediato, feito questão de começar seu artigo ressaltando sua admiração pelo projeto rawlsiano e se alinhando com ele no tocante às intençôes e aos resultados (HABERMAS, I995, p. IIO).

Seus questionamentos diziam respeito à forma como Rawls apresenta seu argumento e às concessóes feitas por ele. De qualquer maneira, as críticas de Habermas podem ser resumidas a três questionamentos gerais. Em primeiro lugar, ele critica a construção da posição original nos moldes rawlsianos, que limita as partes envolvidas a uma autonomia racional, que, por sua vez, 
faz com que elas não sejam capazes de compreender os interesses morais dos representados. As partes da posiçấo original rawlsiana:

são incapazes de alcançar, dentro dos limites definidos por seu egoísmo racional, a reciprocidade de perspectivas que os cidadáos que elas representam precisam adotar quando eles se orientam de maneira justa para o que é igualmente bom para todos (...). Mas, se, apesar disso, é possível para as partes entender o sentido dos princípios deontológicos e levar em conta os interesses de seus clientes pela justiça, elas devem estar equipadas com competências cognitivas que vão além das capacidades que são suficientes para atores racionais que são cegos para questóes de justiça (Ibidem, pp. II2II3, tradução própria).

Para Habermas, esse é um problema que está no coração da "posiçáo original", de forma que as modificaçôes posteriormente feitas por Rawls acabam por levantar dúvidas sobre a própria desejabilidade de tal estratégia argumentativa (Ibidem, p. 133).

Entre as consequências das restriçóes específicas da posição original estaria, por exemplo, o fato de que Rawls se vê obrigado a assimilar direitos a bens para poder inseri-los dentro do conceito de bens primários. Isso porque, do ponto de vista de atores racionais, questôes normativas podem ser representadas somente em termos de bens, o que gera problemas graves:

Precisamente porque Rawls adere a uma concepção de justiça na qual a autonomia dos cidadáos se constitui através de direitos, o paradigma da distribuiçáo gera dificuldades para ele. Direitos podem ser "desfrutados" somente quando são exercidos. Eles não podem ser assimilados a bens distributivos sem perder seu sentido deontológico. Uma igual distribuição de direitos se dá apenas quando aqueles que desfrutam de direitos reconhecem uns aos outros como livres e iguais. Naturalmente, existem direitos a uma justa porçáo de bens ou oportunidades, mas direitos, em primeira instância, regulam relaçóes entre atores; eles não podem ser "possuídos" como coisas (Ibidem, p. II4, tradução própria).

A tentativa de corrigir tal equívoco, no entanto, acaba criando problemas adicionais, uma vez que, a partir do momento em que Rawls tenta compensar acordando prioridade absoluta ao primeiro princípio de justiça e diferencia bens primários constitutivos do quadro de referência institucional de uma sociedade bem ordenada do resto dos bens primários (pela incorporação da garantia de "fair value" da liberdade no primeiro princípio), ele acaba por inserir uma distinçáo entre direitos e bens que contraria a classificaçáo de direitos como bens (Ibidem, p. II6).

A segunda crítica geral feita por Habermas está intimamente relacionada à primeira. Trata-se do fato de que, em última instância, um grande problema da teoria rawlsiana para Habermas é o fato de que ela permanece fixada dentro do paradigma da filosofia da consciência (VANDENBERGHE, op. cit., p. 237, nota 38), ou seja, aplica o imperativo categórico de maneira monológica, o que gera apenas uma multidão de perspectivas individuais isoladas que só poderiam atingir uma 
visão de mundo universalmente válida caso o autoentendimento de cada indivíduo refletisse, como em Kant, uma consciência transcendental, o que, obviamente, não pode ser tomado como ponto de partida nas condiçóes modernas de pluralismo (HaBERMAS, I995, p. II7).

Com essa crítica, Habermas postula uma ética do discurso em que o ponto de vista moral se concretiza a partir da prática intersubjetiva da argumentação.

Por fim, a terceira grande crítica de Habermas é a de que Rawls consegue rebater com mais sucesso: trata-se da questáo da estabilidade e da legitimidade e da suposta necessidade que Rawls teria de desenvolver melhor a diferença entre "aceitabilidade" e "aceitaçáo" (Ibidem, p. I22).

Nesse ponto, vale a pena passarmos logo para a resposta de Rawls, na qual ele distingue três tipos diferentes de justificaçáo e dois tipos de consenso $\mathrm{H}^{\mathrm{II}}$, afirmando que, em consenso sobreposto razoável, os cidadáos encaixam a concepçáo política freestanding de justiça, em suas respectivas doutrinas abrangentes razoáveis, e reconhecendo que os demais fazem o mesmo, o que implica que tal concepçáo política de justiça deve ser justificada publicamente, bem como garantir a estabilidade de uma maneira não apenas instrumental:

A razáo para isso é que quando os cidadáos afirmam doutrinas compreensivas razoáveis, embora diferentes, ver se um consenso sobreposto a respeito da concepção política é possível é um modo de checar se há razóes suficientes para propor a justiça como equidade (...) que possam ser defendidas sinceramente diante de outros, sem criticar ou rejeitar compromissos religiosos e filosóficos mais profundos. (...) O argumento, se bem-sucedido, mostraria como podemos afirmar razoavelmente e apelar a uma concepção de justiça como base das razôes compartilhadas dos cidadáos, supondo sempre que outros, não menos razoáveis do que nós, também podem afirmar e reconhecer essa mesma base. (...) Dada uma sociedade política com um consenso razoável desse tipo, o liberalismo político diz que, como cidadáos dessa sociedade, atingimos a base mais profunda e razoável de unidade social disponível a nós como cidadáos de uma sociedade democrática moderna (RAWLS, 1996, pp. 632-633).

Para Rawls, tal abordagem, que subordina a legitimidade à concepção política de justiça e ao consenso sobreposto razoável, é mais proveitosa do que a ênfase habermasiana direta na questão da legitimidade, pois essa seria uma noçấo mais fraca do que a de justiça (Ibidem, p.

II Os três tipos de justificação identificados por Rawls são: a) a justificação pro tanto da concepção política, isto é, aquele tipo de justificaçăo em que os princípios políticos conseguem dar uma resposta completa às principais questôes de justiça sem recorrer a doutrinas abrangentes; b) a justificaçáo completa, realizada por um indivíduo como membro da sociedade civil, quando ele embute e harmoniza a concepção política previamente com a doutrina abrangente mais geral em que ele acredita; e c) a justificaçáo pública pela sociedade política, que acontece quando "todos os membros razoáveis da sociedade política fazem uma justificação da concepção política partilhada, embutindo-a em suas várias visōes compreensivas razoáveis" e "levam em conta um ao outro como portadores de doutrinas compreensivas razoáveis que endossam essa concepção política" (RAWLS, 1996, p. 63I). Esse terceiro tipo de justificação está intimamente ligada à ideia de consenso sobreposto razoável, que difere daquele consenso típico do dia a dia da política que se apresenta como um mero compromisso ou coalizão de interesses. 
658 e seguintes). Além disso, ao negar que a concepção política de justiça precise lançar mão de conceitos que estejam fora da esfera do "político", Rawls traça uma diferença de escopo entre sua teoria e a de Habermas: para ele, o liberalismo político é de fato uma doutrina freestanding, que se limita a questóes políticas, enquanto a teoria habermasiana, embora de fato semelhante à sua em espírito e em intençôes, constituiria, por si mesma, uma doutrina abrangente, cujo objetivo seria "fornecer uma explicaçáo geral do significado, referência e verdade ou validade tanto para a razão teórica quanto para as várias formas da razão prática” (Ibidem, p. 624).

De resto, Rawls desenvolve argumentos importantes tanto para negar a possibilidade de uma teoria puramente procedimental, o que faz com que ele seja indiferente à objeçáo de Habermas de que sua teoria contém fortes elementos substantivos ${ }^{12}$ (Ibidem, p. 66I), quanto para rebater a acusaçáo de que a justiça como equidade reserva um lugar privilegiado para as liberdades básicas, em detrimento do princípio de soberania popular.

Este último ponto é particularmente interessante: Rawls diz que, como Habermas, defende um ideal democrático em que a autonomia pública e a privada estáo conectadas internamente e que, portanto, em seu liberalismo político, as liberdades básicas não são anteriores à formação da vontade nem estáo inscritas em um domínio pré-político. Tanto a autonomia pública quanto a privada estariam contidas, lado a lado, no primeiro princípio de justiça, e ambas têm sua raiz nos dois poderes morais discriminados por Rawls, ou seja, a capacidade de um senso de justiça e para uma concepção do bem.

Não há, portanto, para Rawls, nenhuma competiçáo mal resolvida entre as liberdades dos modernos e a dos antigos. De todo modo, em nome da ênfase na co-originalidade das duas liberdades, Rawls tenta reduzir suas diferenças em relaçáo ao projeto habermasiano a uma questáo de ênfase pessoal, embora também afirme que, por vezes, Habermas dá uma "ênfase aparente" às liberdades políticas que só seriam plausíveis caso as premissas do humanismo clássico, que postulam que os homens só se realizam plenamente com a atividade política, fossem tomadas como verdadeiras, o que constitui uma generalizaçáo inaceitável (Ibidem, p. 653).

\section{CONCLUSÃO: DUAS ALTERNATIVAS POSSÍVEIS}

Mesmo com todos os seus possíveis problemas internos, as obras de Rawls e Habermas sáo das mais importantes na filosofia política, representando um esforço louvável de resgatar uma perspectiva universalista em um contexto histórico marcado pelo declínio de todos os discursos sobre os fundamentos da sociedade. Ambos tentam formular um ideal normativo compatível com as sociedades contemporâneas capaz de reverter o cinismo e a desilusão que prevalecem na vida cotidiana com respeito às instituições da democracia liberal.

I2 Rawls vê, aqui, a distinção entre justiça procedimental e justiça substantiva como a distinçáo entre a justiça de um procedimento e a de seu resultado. Para ele, como a primeira sempre depende, em alguma medida, da segunda, ambas estão internamente conectadas (Ibidem, p. 654). 
Nos dois casos, a solução é parecida e de inspiração kantiana: trata-se de uma guinada procedimental rumo a uma democracia deliberativa que torne possível a obtençáo de acordos legítimos e racionalmente motivados e que não dependam apenas de cálculos racionais e instrumentais.

Com isso, Rawls e Habermas pretendem conciliar os direitos liberais e o princípio democrático da soberania popular, desfazendo qualquer tensão que possa existir entre eles e afirmando sua co-originalidade (MoufFe, op. cit., p. 8I e seguintes).

No entanto, os obstáculos teóricos encontrados tanto pela justiça como equidade rawlsiana quanto pela perspectiva comunicativa habermasiana são consideráveis. Apesar de ambos terem demonstrado sensibilidade crescente ao que chamamos, junto com Ferrara (op. cit.), de dificuldades do paradigma do julgamento determinante, com base em princípios universais generalizáveis, eles jamais abandonaram de fato tal paradigma.

O resultado é que, com efeito, nenhum dos dois consegue realmente atingir aquilo que almejava. Chantal Mouffe resume a situação com grande elegância quando diz:

Creio que ambos estáo certos em suas respectivas críticas. Com efeito, a concepçáo de Rawls não é táo independente de visôes abrangentes como ele acredita, e Habermas náo pode ser tão puramente procedimental quanto ele alega. Que ambos sejam incapazes de separar o público do privado ou o procedimental do substantivo táo claramente quanto desejam é bastante sugestivo. O que isso revela é a impossibilidade de alcançar o que cada um deles, embora de maneiras diferentes, realmente procura, ou seja, circunscrever um domínio que não estaria sujeito ao pluralismo de valores e onde um consenso sem exclusão pode ser estabelecido (Mouffe, op. cit., p. 9I, traduçáo própria).

Para essa autora:

Rawls e Habermas querem assentar a adesão à democracia liberal em um tipo de acordo racional que exclui a possibilidade de contestaçáo. É por isso que eles precisam relegar o pluralismo para um domínio não público, de forma a insular a política de suas consequências. Que eles não consigam manter a rígida separação que advogam tem implicaçóes muito importantes para a política democrática. Isso sublinha o fato de que o domínio da política - mesmo quando diz respeito a temas fundamentais como a justiça ou os princípios básicos - não é um terreno neutro que pode ser insulado do pluralismo de valores e onde soluçóes racionais e universais podem ser formuladas (Ibidem, p. 93, tradução própria).

A necessidade de abandonar tal perspectiva também é enfatizada no modelo do julgamento refletivo de Ferrara. Tanto a separação nítida e incontroversa entre o bom e o justo quanto a postulação de um momento de necessidade associado ao universal sáo deixadas de lado em prol de uma perspectiva imanente, que, ao exercer a funçấo de espelhar nossas intuiçôes acerca das 
soluçôes justas para as controvérsias práticas, não pode recorrer a qualquer noção, princípio ou ponto de vista externo ao do contexto no qual a controvérsia se desenrola (FerRara, op. cit., p. 179). Isso garante o tom antifundacionalista desse paradigma, que recorre de modo autorreflexivo à noção de autenticidade para elaborar um entendimento da imparcialidade da justiça que seja defensável sem necessidade de sairmos da perspectivas das partes litigantes (FERrARA, op. cit., p. 180):

No processo de interaçáo umas com as outras, as partes para quem a questão da justiça se coloca não podem senão dar origem a uma identidade abrangente comum, não importa quão magra ou mínima, cujo "bem" [good] entendido como realização [fulfillment] é de certa maneira equivalente ao que os teóricos deontológicos chamam de "justiça". (...) Duas concepçôes do bem năo podem ser táo incomensuráveis a ponto de năo conterem nenhum ponto de interseçáo e, ao mesmo tempo, permitirem que aqueles que as adotem entendam suas relaçôes mútuas como envolvidas por conflitos em torno de questốes de justiça (FerRARA, op. cit., pp. 184-I85, tradução própria).

No decorrer de seu livro, Ferrara desenvolve de forma mais específica sua noção de julgamento refletivo, o que ultrapassa o âmbito deste artigo. $\mathrm{O}$ importante a reter de sua enunciaçáo teórica é a forma como ele tenta escapar dos problemas típicos das teorias deontológicas de Rawls e Habermas, a partir da adoçáo de ponto de vista autorreflexivo, que mobiliza o conceito de autenticidade e concebe a imparcialidade e a universalidade da justiça de forma imanente, sem recurso a noçóes transculturais e "a-históricas" que garantam a necessidade do consenso.

Autenticidade e identidade, por sinal, são dois conceitos-chave em diversas tentativas de reinterpretação e formulaçáo de teorias da justiça; não é mera coincidência, por exemplo, que o próprio Axel Honneth, em sua reformulaçáo do agir comunicativo habermasiano, tenha deslocado o foco emancipatório de sua teoria justamente para a questão do reconhecimento, em detrimento da ênfase na racionalização comunicativa do mundo da vida (HoNNETH, I994, p. 302 e seguintes; HoNNETH, 1992).

Para esse autor, a expectativa de ganhar reconhecimento social constitui a pressuposiçáo normativa de toda a açáo comunicativa e reflete as experiências morais dos atores envolvidos na interação.

Já a teoria da democracia agonística de Chantal Mouffe contorna as deficiências dos modelos deontológicos de maneira distinta e ainda mais radical, pois se fundamenta em premissas da abordagem pós-estruturalista desenvolvida por ela e por Ernesto Laclau, em Hegemony and Socialist Strategy (1985).

Para a autora, é preciso partir da constataçáo de que o poder é constitutivo das relaçóes sociais $^{13}$, não sendo possível, portanto, defender a existência de uma esfera pública livre do

I3 Como escreve Mouffe (op. cit., p. 99, tradução própria), "qualquer objetividade social é, em última instância, política e (...) mostra os traços de exclusão que governam sua constituição. O ponto de convergência - ou melhor, de 
poder e da dominação e capaz de produzir consensos racionalmente motivados (Mouffe, op. cit., p. 99). Além disso, não se pode negar a natureza paradoxal da democracia moderna e a tensão fundamental entre a lógica democrática e a lógica liberal, bem como o fato inescapável do pluralismo de valores.

Ao contrário de Rawls, ela insiste na importância de reconhecer a natureza politica - e náo puramente racional - dos limites impostos ao pluralismo e, contra Rawls e Habermas, ela questiona a ênfase excessiva na racionalidade constitutiva das instituiçóes liberais-democráticas, sugerindo que a crença na democracia e em suas instituiçóes depende menos da fundaçáo intelectual que é dada a elas do que de um compromisso com determinada maneira de viver, em que o conflito está presente de forma inescapável, mas os oponentes são vistos como adversários, e não como inimigos.

Em outras palavras, se o consenso sem exclusão implicaria a erradicaçáo do politico, o importante é conceber o outro como um adversário, isto é, alguém cujas ideias nós combatemos, mas cujo direito de defendê-las nós não questionamos, e não como um inimigo a ser destruído. Nessa perspectiva, não é preciso traçar uma distinção entre valores éticos e morais e afastar os primeiros da arena política, muito pelo contrário, e mesmo o consenso mínimo necessário para a organização de tal esquema está fadado a ser um "consenso conflituoso", uma vez que mesmo os valores ético-políticos básicos estáo sujeitos a diferentes interpretaçôes (Ibidem, pp. IO2-IO3).

$\mathrm{Na}$ medida em que todo consenso é, em última instância, uma construçấo hegemônica necessariamente provisória, é inútil e contraproducente trabalhar com um ideal final de "sociedade bem ordenada". A democracia é pensada como um processo do qual o pluralismo de discursos é constitutivo e em que o reconhecimento apropriado da natureza hegemônica das relaçóes sociais ajuda a combater a tentação existente nas sociedades modernas de naturalizar suas fronteiras sociais e culturais e essencializar as identidades (Ibidem, p. IOS).

Como se vê, a proposta de Mouffe é similar à de Ferrara no que diz respeito à negação do momento universal do consenso racional e na forma como evita a separaçấo rígida entre o bem e o justo, a partir do foco na negociação das identidades entre os atores. Embora a apresentaçáo de sua teoria seja necessariamente vaga quanto a diversos pontos, seu tratamento da ubiquidade do poder e sua sensibilidade à violência simbólica conseguem incorporar um viés foucaultiano e bourdieusiano à democracia agonística, sem, no entanto, perder de vista o ideal normativo da democracia como determinada forma de conceber o outro. Mais ainda, o vocabulário da hegemonia e das cadeias de equivalência e diferença (LACLAU \& MoufFE, 1985, p. I27), por sua própria natureza, pode dar conta tanto da reprodução social quanto da possibilidade de inovação,

colapso mútuo - entre objetividade e poder é o que denominamos 'hegemonia'. Essa maneira de colocar a questão indica que o poder náo deve ser concebido como uma relaçáo externa entre duas identidades pré-constituídas, mas sim como constitutivo das identidades elas mesmas. Uma vez que qualquer ordem política é a expressão de uma hegemonia, de um padrão específico de relaçôes de poder, a prática política não pode ser imaginada como simplesmente representativa de identidades pré-constituídas, mas como elemento de constituição dessas identidades em um terreno precário e sempre vulnerável". 
o que é muitas vezes problemático na teoria de Bourdieu, que insiste demasiadamente sobre o primeiro ponto.

Em suma, apesar de propostas bastante distintas teoricamente, tanto Ferrara quanto Mouffe lançam mão de estratégias razoavelmente semelhantes para reformular a perspectiva universalista. Ambos contornam os pontos mais problemáticos das obras de Rawls e Habermas sem, contudo, abrir mão do viés normativo essencial a eles. Nesse contexto, o embasamento teórico da proposta de Mouffe em uma teoria social sólida faz seu modelo de democracia agonística ser particularmente promissor.

\section{FONTES CONSULTADAS}

Ferrara, Alessandro. Justice and judgment - the rise and the prospect of the judgment model in contemporary political philosophy. Londres: Sage Publications, 1999.

Foucault, Michel. "What is Enlightenment?" In: Rabinow, Paul (Ed.) The Foucault reader. Nova York: Pantheon Books, 1984.

Granovetter, Mark. Economic action and social structure: the problem of embeddedness. American Journal of Sociology, v. 91, n. 3, nov. 1985.

HaBERMAS, Jürgen. The theory of communicative action - reason and the rationalization of society. v. I. Boston: Beacon Press, 1987a.

. The theory of communicative action - lifeworld and system: a critique of functionalist reason. v. 2. Boston: Beacon Press, 1987b.

. Reconciliation through the public use of reason: remarks on John Rawls's Political Liberalism. The Journal of Philosophy, v. 92, n. 3, pp. I09-13I, março 1995.

. Direito e democracia: entre facticidade e validade. v. 2. Rio de Janeiro: Tempo Brasileiro, 1997.

HaYeK, Friedrich A. The constitution of liberty. Londres: Routledge, I960.

HonNeth, Axel. Integrity and disrespect: principles of a conception of morality based on the theory of recognition. Political Theory, v. 20, n. 2, pp. I87-20I, maio 1992.

. The social dynamics of disrespect: on the location of critical theory today. Constellations, Oxford, Blackwell Publishers, v. I, n. 2, pp. 255-269, 1994.

LaClau, Ernesto; Mouffe, Chantal. Hegemony and socialist strategy - towards a radical democratic politics. Londres: Verso, 1985. 
Lockwood, David. Social integration and system integration. In: Zollschan, G. K.; Hirsch, H. W. (Eds.) Explorations in social change. Boston: Houghton Miflin, I964.

Lyotard, Jean François. The postmodern condition: a report on knowledge. Minneapolis: University of Minnesota Press, 1984 .

Mouffe, Chantal. For an agonistic model of democracy. In: . The democratic paradox. Londres, Nova York: Verso, 2000.

Nozick, Robert. Anarchy, state, and utopia. Nova York: Basic Book, I974.

Okin, Susan Moller. Reason and feeling in thinking about Justice. Ethics, v. 99, n. 2, pp. 229-249, jan. 1989 .

Rawls, John. A theory of justice. Cambridge: Belknap Press, I97I.

. Political liberalism. Nova York: Columbia University Press, I993.

. Resposta a Habermas. Educação \& Sociedade, ano XVII, n. 57/especial, pp. 62I-673, dezembro 1996.

SAndel, Michael. "Justice and the Good". In: (Ed.) Liberalism and its critics. Nova York: New York University Press, I984.

TAYlor, Charles. "The politics of recognition”. In: Gutmann, Amy (Ed.) Multiculturalism: examining the politics of recognition. Princeton: Princeton University Press, I994.

Vandenberghe, Frédéric. Une histoire critique de la sociologie allemande: alienátion e réification. Tome II: Horkheimer, Adorno, Marcuse, Habermas. Paris: La Découverte, I998. 